\title{
CORRELATION BETWEEN FREQUENCY AND DURATION ON READING THEQUR'AN WITH COGNITIVE FUNCTION AT ELDERLY
}

(Running Head: Reading The Qur'an and Cognitive Function of the Elderly

\section{${ }^{1}$ Pipit Soesilowati Tri Indrijaningrum, ${ }^{* 1}$ Muhammad Hamdan}

ABSTRACT--BackgroundThe population of elderly people in Indonesia is increasing, so decrease of cognitive function will be more common to be found therefore the implementation of cognitive activity of reading as a nonpharmacologically management is needed to maximize cognitive function in elderly.

Objectives:To know the existence of a relation between frequency and duration of reading Al-Quran with cognitive function at elderly.

Methods : This study used case-control and sampling design that conducted according to incident cases. In the study subjects performed cognitive function examination with MoCa-Ina questionnaire, then measured frequency and duration of reading Al-Quran by interview. The data analysis was using Chi-square.

Results : There were 68 study subjects that consisting of 34 subjects with abnormal cognitive function and 34 subjects with normal cognitive. Out of the 34 subjects whose has cognitive abnormal, there was 27 (50.9\%) people who read the Quran with frequency $<12 x /$ week, and 7 (46.7\%) people read with frequency $\geq 12 x /$ week. There was no correlation between the frequency of reading the Quran with cognitive function $(p=0.770)$. Then, 34 subjects whose cognitive abnormal were 14 (40\%) people read the Quran, with a duration of 1 times reading <30 minutes and 20 (60.6\%) people who read the Quran, with a duration of 1 times reading $\geq 30$ minutes.

Conclusion: There was no correlation between the duration of reading the Quran with cognitive function ( $p=$ $0.0890)$

Conclusion : There was no correlation between the frequency and duration of reading the Quran with cognitive function in the elderly.

Keywords---Cognitive Activity, Reading The Quran, Cognitive Function, Elderly, MoCa-Ina

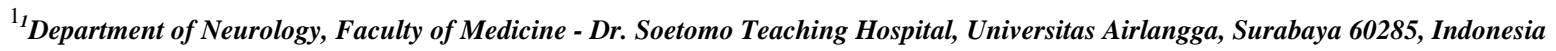
Corresponding Author: Muhammad Hamdan

Department of Neurology, Faculty of Medicine- Dr. Soetomo Teaching Hospital, Universitas Airlangga Mayjen Prof. Dr. Moestopo 47, Surabaya,60285, Indonesia

E-mail:muhammadhamdan.md@gmail.com
} 
International Journal of Psychosocial Rehabilitation, Vol. 24, Issue 02, 2020

ISSN: $1475-7192$

\section{INTRODUCTION}

The elderly population in Indonesia is experiencing an increasing life expectancy, an average increase of up to 70 years. The number of elderly in Indonesia is quite high(1,2).Decreased cognitive function will be increasingly encountered in line with the rapid growth of the elderly(3)thus lead to the urgency of health promotion $(1,4,5)$.The number of people with cognitive impairment is estimated to be about a third of the population over the age of 70 years(6).Previous research mention that about $10 \%$ of parents older than 65 years, and $50 \%$ over 85 will experience cognitive impairment, which will present mild cognitive impairment to dementia(7).

Fifteen percent of individuals with mild cognitive impairment will become demented within 1 year and increase to $50 \%$ chance of becoming dementia within 3 years. Dementia occurs $25 \%$ at age $>75$ years and $40 \%$ at age $>80$ years(8).Treatment of cognitive disorders requires a large cost $(6,9)$.In the United States, cognitive impairment becomes the largest contributor of inpatients by $40 \%$ (10). While in the UK, 800.000-900.000 people with dementia are estimated to cost 22-23 billion annually, and dementia maintenance costs in 2060 in Australia that expected to swallow the entire health budget(11).

Cognitive function is one factor that affects independence, quality of life $(12,13)$ and survival in elderly(9).The poor cognitive function is also a predictor of death and as a marker of general health status in the elderly 1.Management of cognitive impairment is best performed as early as prevention or maintaining cognitive function(14), thereby improving quality of life, prolonging self-reliance and reducing economic and social burdens.

Nonpharmacological management is important, especially for the elderly population at greatest risk of side effects from polypharmacy(15).Reading is part of the cognitive activity and one of the non-pharmacological management to maximize cognitive function in the elderly(16).Reading the holy book of the Qur'an, was part of the cognitive activity, also part of the religious activity. One of the factors of active aging by the program of the World Health Organization (WHO). Active aging is the process of optimizing the opportunity to be healthy, participating and safe to improve the quality of life in elderly. The word 'active' is meant to remain actively participating in the social, economic, cultural, and spiritual/religious fields, not just the ability to become physically active as a workforce(17).This study was aimed to know the existence of a relation between frequency and duration of reading Al-Quran with cognitive function at elderly and expected to be used as one of the easiest and inexpensive ways to maintain cognitive function or slowing the decline in cognitive function in the elderly.

\section{METHODS}

The type of research conducted was observational analytic and the design used was case-control. This design was chosen because it considered in accordance with the problems studied and the objectives to be achieved. The subjects of the study were elderly men and women of Islam aged 45-70 years who could read the Quran, could read and write, and were willing to participate the research, and Moca-Ina <26 test and lived in old age community of Gubeng Village and Airlangga, Surabaya. This research was conducted in June 2016 to June 2017 from literature to research report. The implementation of research conducted in January to May 2017.

Reading the Quran is a reading activity by opening the holy book of the Quran (hijaiyah) instead of iqro by seeing and issuing a voice regardless of the meaning or not, and not the act of memorizing the Quran. People who could read the Quran, frequency, and duration of reading determined based on the interview. In this study was assessed the activity of reading Al-Quran own. 
International Journal of Psychosocial Rehabilitation, Vol. 24, Issue 02, 2020

ISSN: $1475-7192$

The frequency of reading the Quran, the number of times study subjects read the Quran in 1 week were being observed. The frequency data will be presented in a categorical form that was rarely (<cut off point) and frequent $(\geq$ cut off point). The duration of reading the Quran, how long the study subjects read the Quran (in minutes) for once read. Data curation will be presented in the form of categorical that was short (cut off point) and long ( $\geq$ cut off point). Confounding variables include age, education, diabetes mellitus, hypertension,hypercholesterolemia and smokers.

Cognitive function is the cognitive ability measured by using MoCA-Ina test which yields the measuring value. Interpretation of the test is if the score $\geq 26 / 30$ - 30/30 points mean normal, and <26 points means any cognitive/abnormal disturbance. Points added 1 if the subject has a history of $\leq 12$ years. Data cognitive function will be presented in the form of categorical cognitive abnormal and normal.

The research instrument used a patient data collection sheet. Examination of cognitive function was performed by using MoCA-Ina. Research procedure was all subjects included in the inclusion criteria and given an explanation of the purpose and usefulness of the study, then asked to participate in the study without coercion. At the end, If the subject has understood and agreed, then asked to sign a consent statement by following the research.

This study has received an ethical eligibility letter at the Research Ethics Committee of RSUD dr. Soetomo / FK Universitas Airlangga Surabaya.The data obtained from the data collection sheet that later being analyzed. The correlation between elderly frequent and rare, short and long of reading the Quran with cognitive function in the elderly was calculated and analyzed by appropriate statistical tests using SPSS 20.

\section{RESULTS}

Demographic data include sex, age, education level, marital status, and occupation. (Table 1). Clinical data of study subjects include cognitive function, hypertension, diabetes mellitus, hypercholesterolemia, smoking, frequency, and duration of reading the Quran (Table 2). Out of 34 subjects with abnormal cognitive was 28 (48.3\%) with age $\geq 60$ years, and $6(60 \%)$ by $<60$ years old. There was no significant correlation between age and cognitive function statistically $(\mathrm{p}=0.493)$ (Table 3).

In addition, out of 34 subjects with abnormal cognitive, there was 29 (52.7\%) people with education level $\leq 12$ years and $5(38.5 \%)$ with education level $>12$ years. There was no significant relationship between educational level and cognitive function statistically $(\mathrm{p}=0.355)$ (Table 4$)$.Then, out of 34 subjects with abnormal cognitive, there by $16(43.2 \%)$ people with hypertension and $18(58.1 \%)$ was not hypertensive. There was no significant correlation between hypertension and cognitive function statistically $(\mathrm{p}=0.223)$ (Table 5).However, out of 34 subjects with abnormal cognitive, there was 9 (47.4\%) people with Diabetes Mellitus and 25 people (51\%) with no DM. There was no significant association between DM and cognitive function statistically $(\mathrm{p}=0.787)$ (Table 6).

Then, out of 34 subjects with abnormal cognitive, there was 21 (51.2\%) people with hypercholesterolemia and 13 (48.1\%) with no hypercholesterolemia. There was no significant association between hypercholesterolemia and cognitive function statistically $(\mathrm{p}=0.804)$ (Table 7).Then, 34 subjects with abnormal cognitive, there were no smokers $(0 \%)$ and $34(50.7 \%)$ non-smokers. No analysis could be made of the correlation between smokers and cognitive function (Table 8).Addition, out of the 34 subjects whose cognitive abnormal, there was 27 (50.9\%) people read the Quran with frequency $<12$ times/week (rare), and 7 (46.7\%) people with frequency $\geq 12$ times/week (frequent). There was no correlation between the frequency of reading the Quran and cognitive function with cut off 
International Journal of Psychosocial Rehabilitation, Vol. 24, Issue 02, 2020

ISSN: $1475-7192$

point 12 times/week $(\mathrm{p}=0.770)$ (Table 9). There was no correlation between reading frequency of the Quran and cognitive function, with the cut off point in each frequency.

Then, out of the 34 subjects whose cognitive abnormalities was 14 (40\%) people read the Quran, with a duration of once times read $<30$ minutes (briefly) and 20 people (60.6\%) who read Al-Quran, with a duration of once times reading $\geq 30$ minutes (long). There was no correlation between the duration of reading the Quran with cognitive function with a 30 minute cut off point $(\mathrm{p}=0.0890)$ (Table 10). There was no relationship between the duration of reading the Quran with cognitive function, with a cut off point in each duration.

Based on 68 subjects, we obtained 27 subjects who read the Quran every day by using a 120-month cut-off point. There was 15 people with abnormal cognitive that consisting of 10 (62.5\%) people reading the Quran daily from $<120$ months, and 5 people (45.5\% ) read the Quran every day since $\geq 120$ months. There was no significant relationship between how long to read the Quran every day with statistical cognitive function. $(\mathrm{p}=0.452)$ (Table 11).

\section{DISCUSSION}

The study showed there was no relationship between the frequency and duration of reading the Koran with cognitive function in old age. The intensity of cognitive activity is difficult to measure, varies between individuals, and between various activities(13).Based on the results of a review by Sajeev et al mentions that cognitive activity in old age has the opportunity to reduce the risk of DA and other dementias, but more data are needed much to confirm about the relationship between them, the optimal type of activity, duration, intensity, and time(18).The study also explained that there was no relationship between how long reading the Koran each day with cognitive function, however, the subject who read the Koran every day for a long time found a tendency to have abnormal cognitive with smaller proportions. Apart from that, the study studied can be used as a reference to confirm further understanding of the correlation of the frequency and duration of Al-Qur'an reading on the cognitive function of the elderly considering that little attention has been paid to the issue.

There was no significant association between confounding variables and cognitive function in elderly. Research subjects were mostly female (88.4\%), aged $\geq 60$ years $(85.3 \%)$, educated $\leq 12$ years $(80.9 \%)$, married and spouse still alive (75\%), working as housewives (61.7\%). Along with the increasing of age then the cognitive function will decrease(19).Table 3 shows the relationship between age and cognitive function. Furthermore, education has a protective effect on memory function, crystallized intelligence and minimal effect on fluid cognition(20)Table 4 shows the relationship between education level and cognitive function. Thus Table 5 shows the relationship between hypertension and cognitive function. Uncontrolled hypertension causes a negative effect on independent cognitive functioning apart from the aging factor(21).Long-term blood pressure reductions improve cognitive functioning, especially the function of the executive despite the large cerebrovascular damage(22). A total of 24 (65\%) people of 37 research subjects with hypertension had received antihypertensive therapy.Hencetable 6 also shows the relationship between diabetes mellitus and cognitive function. Earlier study mentioned that cognitive dysfunction in patients with diabetes mellitus was associated with poor sugar control(23). Patients who were not treated, compared to patients receiving treatment had a 2-point decrease in MMSE values within 2 years with a long duration of $>5$ years of illness24. A total of 17 people (89.5\%) of 19 subjects with Diabetes Mellitus have received treatment to control their blood sugar levels. Moreover, The result of data analysis showed there was no significant correlation between hypercholesterolemia with statistical cognitive function that is shown at table 7 . 
International Journal of Psychosocial Rehabilitation, Vol. 24, Issue 02, 2020

ISSN: $1475-7192$

Increased total cholesterol, Low-density lipoprotein (LDL), Very Low-density lipoprotein (VLDL) and LDL/High -Density Lipoprotein (HDL) ratios were associated with impaired MMSE values. Cholesterol, especially LDL is the most significant risk factor, especially on the subject who also smoked, while in this study was not checked LDL levels(24). Other studies have shown that there was no evidence of an association between blood cholesterol and cognitive ability(25).

There was a negative effect of smoking on cognitive function that consistent with the results of the systematic review, which suggests that smoking causes poorer cognitive abilities in middle age to old age(25). From table 8 shows the relationship between smokers with cognitive function. There were no smokers in the group with abnormal cognitive function.

In this study used to cut off point on each frequency that exists. The result of statistical analysis did not get the relationship between the frequency with cognitive function by using cut off point at each frequency. Table 9 shows the relationship between the frequency of reading the Quran and the cognitive function using a cut-off point of 12 times/week. From the results of the analysis, there was no correlation between the frequency of reading the Quran with the cognitive function in a statistical manner. The results of this study were in accordance with research by Geda et al that there was no correlation between reading frequency (magazine and newspaper) with risk of mild cognitive impairment(26),

However, there are several differences with the aforementioned study. In research conducted by Geda that involving subjects of research aged 70-89 years and measured the activity of reading books in 1 month(26), while in this study age of research subjects 45-70 years and measured the activity of reading the Quran in 1 week. In addition, the tool used to measure cognitive function in this study was the MoCA-Ina test that more sensitive in detecting the presence of cognitive dysfunction while the previous study was by using the Mini-Mental State Examination(MMSE)(27). In the study by Verghese et al, the older study subjects of age 75-85 years and the assessed output was dementia(28), whereas in this study the age of subjects 45-70 years with abnormal or normal cognitive output. The cause of no correlation between the frequency of reading the Quran with cognitive functioning possibility due to high subjectivity of the research subject, the small sample size ( $\beta$ error $=94 \%$ at cut off point 12 times/week), the researcher did not prove whether the subject research could indeed read the Quran and with the frequencies mentioned by the research subjects.

Research subjects who read the Quran more frequently ( $\geq 12$ times/week and $\geq 14$ times/week) showed a tendency to have abnormal cognitive function with a smaller proportion of $46.7 \%$ and $42.9 \%$. By using the cut-off point on each duration of reading the Quran, there was no relationship between the duration of reading the Quran and cognitive function. Table 10 shows the relationship between the duration of reading the Quran and the cognitive function using a 30-minute cut-off point. The results of this study were in accordance with research by Wang et albut in contrast to some of the following studies(16,29). Research with reading and writing for 3 months, 3 times/week, and 30 minutes/session improves memory function in subjects with MCI age 50-70 years.A 15-minute study of reading the Quran improved memory function. The cause of no significant relationship between the duration of reading the Quran and cognitive function could be due to the high subjectivity of the research subjects, small sample size ( $\beta$ error $=60 \%$ at the cut-off point 30 minutes). Furthermore, from the data on subjects who read the Quran every day since long time ago has obtained the tendency to have abnormal cognitive with a smaller proportion 
International Journal of Psychosocial Rehabilitation, Vol. 24, Issue 02, 2020

ISSN: $1475-7192$

Based on the literature it was obtained that individuals who had higher levels of cognitive activity over a lifetime (as measured by Lifetime of Experiences Questionnaire (LEQ) had smaller hippocampal atrophy of $3.6 \%$ for 3 years, whereas individuals with lower cognitive activity levels experienced hippocampal atrophy $8.3 \%$ for 3 years $(\mathrm{p}=$ 0.042)32.Individuals who more often perform cognitive activities throughout their lives was correlating with slower cognitive decline(30). Overall, the study is contributed in extending the literature about cognitive function in elderly. However, the study has several limitations1) Researchers did not prove whether the research subjects really could read the Koran and with the frequency and duration mentioned by the research subjects; (2) This research does not analyze other cognitive activities (writing, playing puzzles, gardening, cooking, sewing, knitting, etc.), physical activity, social involvement, which can affect cognitive function; (3) This research does not analyze other confounding factors such as socioeconomic status/ (4) smallsamplesize.

\section{CONCLUSION}

The study found that there was no correlation between the frequency and duration of reading the Quran with cognitive function in the elderly.Confounding variables studied also show a non-significant relationship on the functioning of the elderly congnitive. Further research needs to be done using this type of interventional or observational research with a cohort study design and paying more attention to other confounding factors not analyzed in this study, or by using more objective measurement tools (standardized questionnaires, diaries, or timekeeping devices) and enlarge the sample.

\section{REFERENCES}

[1] Berniyanti T, Palupi R, Setijanto RD, Bramantoro T, Nur I, Ramadhani A. Overview of Dentures' Demand to Support the Improvement of Life Quality of the Elderly at High- Level Life Expectancy in Indonesia. J Int Oral Heal. 2019;11(3):112-7.

[2] Anna NEV, Mannan EF, Srirahayu DP. Evaluation of the Role of Society-Based Library in Empowering Surabaya City People. Public Libr Q. 2019;1-13.

[3] Jak AJ. The impact of physical and mental activity on cognitive aging. In: Behavioral Neurobiology of Aging. Springer; 2011. p. 273-91.

[4] Kushariyadi K. Memory Stimulation, Intervention Increase Elderly Cognitive Function. J Ners. 2017;8(2):317-29.

[5] Bramantoro T, Rizal S, Palupi R, Setijanto D, Wening GRS, Kusumo AD. Interventive empowerment program to improve dental health knowledge for people living with HIV, teenagers, and visitors of public health center in red district area. J Int Oral Heal. 2019;11(7):22.

[6] Fisher GG, Stachowski A, Infurna FJ, Faul JD, Grosch J, Tetrick LE. Mental work demands, retirement, and longitudinal trajectories of cognitive functioning. J Occup Health Psychol. 2014;19(2):231.

[7] Yaffe K, Barnes D, Nevitt M, Lui L-Y, Covinsky K. A prospective study of physical activity and cognitive decline in elderly women: women who walk. Arch Intern Med. 2001;161(14):1703-8.

[8] Fillit HM, Butler RN, O'connell AW, Albert MS, Birren JE, Cotman CW, et al. Achieving and maintaining cognitive vitality with aging. In: Mayo Clinic Proceedings. Elsevier; 2002. p. 681-96.

[9] Aartsen MJ, Smits CHM, Van Tilburg T, Knipscheer KCPM, Deeg DJH. Activity in older adults: cause or consequence of cognitive functioning? A longitudinal study on everyday activities and cognitive performance in older adults. Journals Gerontol Ser B Psychol Sci Soc Sci. 2002;57(2):P153-62.

[10] Deary IJ, Corley J, Gow AJ, Harris SE, Houlihan LM, Marioni RE, et al. Age-associated cognitive decline. Br Med Bull. 2009;92(1):135-52.

[11] Marioni RE, Valenzuela MJ, Van den Hout A, Brayne C, Matthews FE. Active cognitive lifestyle is associated with positive cognitive health transitions and compression of morbidity from age sixty-five. PLoS One. 2012;7(12):e50940.

[12] Yusuf A, Indarwati R, Jayanto AD. SENAM OTAK MENINGKATKAN FUNGSI KOGNITIF LANSIA 
(Brain Gym Improves Cognitive Function for Elderly). J Ners.

[13] Williams KN, Kemper S. Interventions to reduce cognitive decline in aging. J Psychosoc Nurs Ment Health Serv [Internet]. 2010 May;48(5):42-51. Available from: https://www.ncbi.nlm.nih.gov/pubmed/20415290

[14] Leung GTY, Fung AWT, Tam CWC, Lui VWC, Chiu HFK, Chan WM, et al. Examining the association between late- life leisure activity participation and global cognitive decline in community- dwelling elderly Chinese in Hong Kong. Int J Geriatr Psychiatry. 2011;26(1):39-47.

[15] Ruthirakuhan M, Luedke AC, Tam A, Goel A, Kurji A, Garcia A. Use of physical and intellectual activities and socialization in the management of cognitive decline of aging and in dementia: a review. J Aging Res. 2012;2012.

[16] Hughes TF, Chang C-CH, Vander Bilt J, Ganguli M. Engagement in reading and hobbies and risk of incident dementia: the MoVIES project. Am J Alzheimer's Dis Other Dementias®. 2010;25(5):432-8.

[17] WHO. Active aeging: a policy framework. A contribution of the World Health Organization to the Second United Nations World Assembly on Ageing,. In Madrid, Spain; 2002. Available from: http://apps.who.int/iris/bitstream/10665/67215/1/WHO_NMH_NPH_02.8.pdf

[18] Sajeev G, Weuve J, Jackson JW, VanderWeele TJ, Bennett DA, Grodstein F, et al. Late-life cognitive activity and dementia: a systematic review and bias analysis. Epidemiology. 2016;27(5):732.

[19] Harada CN, Love MCN, Triebel KL. Normal cognitive aging. Clin Geriatr Med. 2013;29(4):737-52.

[20] Muzamil MS, Afriwardi A, Martini RD. Hubungan antara tingkat aktivitas fisik dengan fungsi kognitif pada usila di Kelurahan Jati Kecamatan Padang Timur. J Kesehat Andalas. 2014;3(2).

[21] Myers JS. Factors associated with changing cognitive function in older adults: Implications for nursing rehabilitation. Rehabil Nurs. 2008;33(3):117-23.

[22] Semplicini A, Inverso G, Realdi A, Macchini L, Maraffon M, Puato M, et al. Blood pressure control has distinct effects on executive function, attention, memory and markers of cerebrovascular damage. J Hum Hypertens. 2011;25(2):80.

[23] Munshi M, Grande L, Hayes M, Ayres D, Suhl E, Capelson R, et al. Cognitive dysfunction is associated with poor diabetes control in older adults. Diabetes Care. 2006;29(8):1794-9.

[24] TEKİN O, ÖZKARA A, Yanik B, YİĞíTOĞLU MR, Ilhan A, Kibrisli E, et al. Effects of plasma lipids and smoking on cognitive function. Turkish J Med Sci. 2011;41(2):193-204.

[25] Okusaga O, Stewart MCW, Butcher I, Deary I, Fowkes FGR, Price JF. Smoking, hypercholesterolaemia and hypertension as risk factors for cognitive impairment in older adults. Age Ageing. 2013;42(3):306-11.

[26] Geda YE, Topazian HM, Lewis RA, Roberts RO, Knopman DS, Pankratz VS, et al. Engaging in cognitive activities, aging, and mild cognitive impairment: a population-based study. J Neuropsychiatry Clin Neurosci. 2011;23(2):149-54.

[27] Koenig HG, George LK, Titus P. Religion, spirituality, and health in medically ill hospitalized older patients. J Am Geriatr Soc. 2004;52(4):554-62.

[28] Verghese J, Lipton RB, Katz MJ, Hall CB, Derby CA, Kuslansky G, et al. Leisure activities and the risk of dementia in the elderly. N Engl J Med. 2003;348(25):2508-16.

[29] Nahid S, Hassan K, Maryam N, Pouneh M. The effects of physical an d mental activity on the memory in 50-70 year-old women with mild cognitiv e impairment. Eur J Experi Biol. 2013;3:353-62.

[30] Wilson RS, Boyle PA, Yu L, Barnes LL, Schneider JA, Bennett DA. Life-span cognitive activity, neuropathologic burden, and cognitive aging. Neurology. 2013;81(4):314-21.

\section{TABLES}

Table 1: Demographic data of research subjects

\begin{tabular}{lll}
\hline Variable & Amount & Percentase (\%) \\
\hline Sex & 8 & 11.76 \\
Male & 60 & 88.24 \\
Female & & \\
\hline Age & 10 & 14.7 \\
$<60$ y/o & 58 & 85.3 \\
$\geq 60$ y/o & \\
\hline Education Level & \\
\hline
\end{tabular}


International Journal of Psychosocial Rehabilitation, Vol. 24, Issue 02, 2020

ISSN: $1475-7192$

\begin{tabular}{lll}
\hline \multicolumn{1}{c}{$\begin{array}{c}\leq 12 \text { year } \\
\quad>12 \text { year }\end{array}$} & 55 & 80.9 \\
Job & 13 & 19.1 \\
$\quad$ Housewife & 42 & 61.7 \\
Pension & 17 & 25 \\
$\quad$ Self-managed & 8 & 11.8 \\
$\quad$ Unemploye & 1 & 1.5 \\
\hline Marriage Status & & \\
Married, and the parther still & 51 & 75 \\
alive & 16 & 23.5 \\
Widow/Widower & 1 & 1.5 \\
Un-married & & \\
\hline
\end{tabular}

Table 2: Clinical Data of Subject Research

\begin{tabular}{lll}
\hline Variable & Amount & Percentase (\%) \\
\hline Cognitive & 34 & 50 \\
Abnormal & 34 & 50 \\
Normal & 37 & 54.4 \\
\hline Hypertension & 31 & 45.6 \\
Yes & 19 & 27.9 \\
No & 49 & 72.1 \\
\hline Diabetes Melitus & & \\
Yes & 41 & 60.3 \\
No & 27 & 39.7 \\
\hline Hypercholesterolemia & 1 & \\
Yes & 67 & 98.5 \\
No & & \\
\hline Smoker & & \\
Yes & & \\
No & &
\end{tabular}

Frequency of reading the

Quran in a week

$\begin{array}{lll}<12 \text { times } & 53 & 77.9 \\ \geq 12 \text { times } & 15 & 22.1\end{array}$

The duration of reading the

Quran in 1 time reading
$<30$ menit
35
51.5 
International Journal of Psychosocial Rehabilitation, Vol. 24, Issue 02, 2020

ISSN: $1475-7192$

\begin{tabular}{lll}
\hline$\geq 30$ menit & 33 & 48.5 \\
\hline
\end{tabular}

Table 3: Correlation between age and cognitive function

\begin{tabular}{llllll}
\hline \multirow{2}{*}{ Age } & \multicolumn{2}{c}{ Cognitive } & Total & P & RO (CI95\%) \\
\cline { 2 - 3 } & Abnormal & Normal & & 58 & \\
\hline 60 & & & & \\
& $28(48.3 \%)$ & $30(51.7 \%)$ & $(100 \%)$ & 0.493 & 0.622 \\
& $6(60 \%)$ & $4(40 \%)$ & 11 & & $(0.159-2.439)$ \\
\hline Total & 34 & 34 & $(100 \%)$ & 68 & \\
\hline
\end{tabular}

Table 4: Correlation between education level and cognitive function

\begin{tabular}{|c|c|c|c|c|c|}
\hline \multirow{2}{*}{$\begin{array}{l}\text { Education } \\
\text { Level }\end{array}$} & \multicolumn{2}{|l|}{ Cognitive } & \multirow{2}{*}{ Total } & \multirow{2}{*}{$\mathrm{P}$} & \multirow{2}{*}{ RO (CI95\%) } \\
\hline & Abnormal & Normal & & & \\
\hline$\leq 12$ year & & & 55 & \multirow{4}{*}{0.355} & \multirow{4}{*}{$\begin{array}{l}1.785 \\
(0.518-6.145)\end{array}$} \\
\hline \multirow[t]{3}{*}{$>12$ year } & $29(52.7 \%)$ & $26(47.3 \%)$ & $(100 \%)$ & & \\
\hline & $5(38.5 \%)$ & $8(61.5 \%)$ & 13 & & \\
\hline & & & $(100 \%)$ & & \\
\hline Total & 34 & 34 & 68 & & \\
\hline
\end{tabular}

Table 5: Correlation between Hypertension and Cognitive Function

\begin{tabular}{cccccc}
\hline \multirow{2}{*}{$\begin{array}{c}\text { Hypertensi } \\
\text { on }\end{array}$} & Cognitive & Total & P & RO (CI95\%) \\
\cline { 2 - 4 } & Abnormal & Normal & & & \\
\hline Yes & & & 37 & & \\
No & $16(43.2 \%)$ & $21(56.8 \%)$ & $(100 \%)$ & 0.223 & 0.550 \\
& $18(58.1 \%)$ & $13(41.9 \%)$ & 31 & & $(0.210-1.445)$ \\
& & & $(100 \%)$ & & \\
\hline Total & 34 & 34 & 68 & & \\
\hline
\end{tabular}

Table 6: Correlation between Diabetes Mellitus and Cognitive Function

\begin{tabular}{llllll}
\hline DM & Cognitive & & Total & P & RO (CI95\%) \\
\cline { 2 - 3 } & Abnormal & Normal & & & \\
\hline Yes & $9(47.4 \%)$ & $10(52.6 \%)$ & $19(100 \%)$ & \multirow{2}{*}{0.787} & 0.864 \\
No & $25(51 \%)$ & $24(49 \%)$ & $49(100 \%)$ & & $(0.299-2.495)$ \\
\hline Total & 34 & 34 & 68 & & \\
\hline
\end{tabular}


International Journal of Psychosocial Rehabilitation, Vol. 24, Issue 02, 2020

ISSN: $1475-7192$

Table 7: Correlation between Hypercholesterolemia and Cognitive Function

\begin{tabular}{|c|c|c|c|c|c|}
\hline \multirow{2}{*}{$\begin{array}{l}\text { Hypercholesterolemi } \\
\text { a }\end{array}$} & \multicolumn{2}{|l|}{ Cognitive } & \multirow[t]{2}{*}{ Total } & \multirow[t]{2}{*}{$\mathrm{P}$} & \multirow[t]{2}{*}{$\mathrm{RO}(\mathrm{CI} 95 \%)$} \\
\hline & Abnormal & Normal & & & \\
\hline Yes & & 20 & & & \\
\hline \multirow[t]{3}{*}{ No } & $21(51.2 \%)$ & $(48.8 \%)$ & $41(100 \%)$ & 0.8 & 1.131 \\
\hline & $13(48.1 \%)$ & 14 & $27(100 \%)$ & 04 & $(0.428-2.989)$ \\
\hline & & $(51.9 \%)$ & & & \\
\hline Total & 34 & 34 & 68 & & \\
\hline
\end{tabular}

Table 8: Correlation between Smoker and Cognitive Function

\begin{tabular}{llllll}
\hline Smoker & Cognitive & & Total & P & RO (CI95\%) \\
\cline { 2 - 3 } & Abnormal & Normal & & \\
\hline Yes & $0(0 \%)$ & $1(100 \%)$ & $1(100 \%)$ & \\
No & $34(50.7 \%)$ & $33(49.3 \%)$ & $67(100 \%)$ & \\
\hline Total & 34 & 34 & 68 & \\
\hline
\end{tabular}

Table 9: Correlation between Frequency of reading the Quran and Cognitive Function

\begin{tabular}{llllll}
\hline \multirow{2}{*}{ Frequency } & \multicolumn{1}{l}{ Cognitive } & Total & P & RO (CI95\%) \\
\cline { 2 - 3 } & Abnormal & Normal & & & \\
\hline$<12 \mathrm{x}$ & $27(50.9 \%)$ & $26(49.1)$ & $53(100 \%)$ & \multirow{2}{*}{0.770} & 1.187 \\
$\geq 12 \mathrm{x}$ & $7(46.7 \%)$ & $8(53.3)$ & $15(100 \%)$ & & $(0.376-3.742)$ \\
\hline Total & 34 & 34 & 68 & &
\end{tabular}

Table 10: Correlation between Reading the Quran Duration and Cognitive Function

\begin{tabular}{lllll}
\hline Duration(minut & Cognitive & Total & P & RO (CI95\%)
\end{tabular}

e)

\begin{tabular}{llllll}
\cline { 2 - 3 } & Abnormal & Normal & & \\
\hline$<30$ & $14(40 \%)$ & $21(60 \%)$ & $35(100 \%)$ & 0.089 & 0.433 \\
$\geq 30$ & $20(60.6 \%)$ & $13(39.4 \%)$ & $33(100 \%)$ & & $(0.164-1.145)$ \\
\hline Total & 34 & 34 & 68 & &
\end{tabular}

Table 11: Correlation between how long Read the Quran daily and Cognitive Function

\begin{tabular}{llllll}
\hline \multirow{2}{*}{$\begin{array}{c}\text { How long has it been } \\
\text { to read the Quran daily? }\end{array}$} & Cognitive & & Total & P & RO (CI5\%) \\
\cline { 2 - 4 }$($ month) & Abnormal & Normal & & \\
\hline$<120$ month & $10(62.5 \%)$ & $6(37.5 \%)$ & $16(100 \%)$ & \multirow{2}{*}{0.452} & 2 \\
$\geq 120$ month & $5(45.5 \%)$ & $6(54.5 \%)$ & $11(100 \%)$ & & $(0.420-9.516)$ \\
\hline Total & 15 & 12 & 27 & \\
\hline
\end{tabular}

